\title{
An-Natiq
}

Jurnal Kajian Islam Interdisipliner

Volume 01 Nomor 02 Tahun 2021

e-ISSN: 2777-0176 | p-ISSN: 2798-0200

\section{KREATOR VIDEO DAKWAH INSTAGRAM: KAJIAN TERHADAP AKUN FUADBAKH}

\author{
Romario \\ Sekolah Tinggi Ilmu Tarbiyah Hamzah Fansuri \\ e-mail: roma02711@gmail.com
}

\begin{abstract}
Social Media as a free space provides freedom for anyone to fill in the contents and writings, this also does not escape the use of the Islamist movement which massively utilizes social media to embed ideas. Various kinds of social media platforms such as Facebook, WattApp, Twitter, Youtube, and Instagram are utilized by filling in content and lectures from Islamic clerics who have radical narratives. In this study, I will focus on how the Fuadbakh account that posts religious narratives by cutting the video of the interpreter and various edited videos. The account was chosen in popularity among teenagers as a content creator who made religious videos. In this study, I will explore the profile of Fuadbakh who has 1 million followers and 1,750 potentials, and removes several posts from the Fuadbakh account. The results of this study show short video posts from Fuadbakh, many made to discuss political issues, especially those that intersect with religion, video clips are usually taken from television shows such as ILC which are then combined with other texts and videos.
\end{abstract}

Keywords: fuadbakh, instagram, konten kreator

\section{A. Pendahuluan}

Media Sosial sebagai ruang bebas memberikan kebebasan bagi siapapun mengisi konten-konten dan tulisan, hal ini pun tak luput dimanfaatkan gerakan Islamis yang dengan massif memanfaatkan media sosial menyemaikan gagasan. Berbagai macam plaftform media sosial seperti Facebook, WattApp, Twitter, Youtube, dan Instagram dimanfaatkan dengan mengisi konten dan ceramah dari ustaz "islamis" yang memiliki narasi-narasi radikal. PPIM UIN Jakarta memetakan situs dakwah yang membawa pesan Islam keras seperti eramuslim.com, VOA-Islam, arrahman.com, dan thoriquna. Com. Perkembangan dari situs menuju media sosial juga membawa transisi pesan Islam keras yang sebelumnya ada di situs. Salah satu media sosial yang dijadikan sebagai tempat dakwah Islam keras adalah Instagram.

Kajian mengenai media sosial Instagram dan keagamaan dikaji beberapa sarjana, (Baulch \& Pramiyanti, 2018; Nisa, 2018; Jannah, 2018; Saifullah, 2018). Nisa (2018) memfokuskan kajian terhadap akun Ukhtisally dan Duniajilbab yang 
menggunakan akun tersebut sebagai dakwah kreatif untuk menggabarkan muslimah idela sekaligus menjadi bisnis kreatif dalam memasarkan produka pakaian muslimah yang ideal. Senada dengan Nisa, Baulch dan Pramiyanti (2018) mengkaji akun-akun Hijabber yang mempromosikan bagaiman muslimah yang ideal. Sedangkan Jannah (2018) mengkaji bagaimana kontestasi makna hijab antara akun HijabberCommunity dan NiqabSquad, HijabberCommunity memaknai hijab degan tetap menutup aurat namun bisa tampi trendy, sedangkan NiqabSquad menjadikan makna hijab sebagai muslimah ideal yang bercadar. Berbeda dengan penelitian sebelumnya yang memfokuskan mengenais muslimah, Saifullah (2018) memfokuskan kajian terhadap akun taaruf_nikah yang menjadi media sosial instagram sebagai tempat mencari jodoh..

Studi sebelumnya banyak memfokuskan mengenai akun-akun muslimah yang mendakwahkan bagaimana muslimah yang ideal. Dalam kajian ini kami akan memfokuskan bagaimana akun Fuadbakh yang memposting narasi-narasi keagamaan dengan memotong video pencermah dan berbagai video yang diedit. Akun tersebut dipilih kepopuleran dikalangan generasi remaja sebagai conten creator yang membuat video keagamaan. Dalam kajian ini saya akan menggali profil Fuadbakh serta menganilis beberapa postingan dari akun fuadbakh.

\section{B. Metode}

Secara metodologi penelitian menggunakan metode kualitatif dengan memakai teori yang digunakan Robert N. Entman yang melihat bagaimana sebauah isu atau wacana disampaikan di ruang public dengan melihat aspek-aspek yang ditonjolkan. Objek dalam penelitian ini adalah akun instagram @fuadbakh, akun ini dipilih karena Fuadbakh banyak memposting narasi-narasi keagamaan dengan memotong video penceremah dan berbagai video yang diedit. Akun tersebut juga populer di kalangan generasi remaja sebagai conten creator yang membuat video keagamaan.

\section{Otoritas Agama Baru}

Sebelum mengkaij mengenai fuadbakh, terlebih dahulu saya akan memaparkan bagaimana media memunculkan otoritas baru. Merujuk kepada Eickelman \& Anderson, (2003) bahwa media baru memunculkan otoritas keagamaan baru yang berbeda dengan otoritas lama, dimana otoritas baru ini memiliki kemampuan dalam entertaiment sehingga mampun menarik banyak pengikut. Hal sama juga dikatakan Turner (2007) bahwa otoritas baru ini tidak memiliki latar belakang pengetahuan agama yang kuat. Fealy \& White (2008) mengamati fenomena kemunculan otorita baru di Indonesia yang iya sebut dengan "Ustaz Seleb" atau disebut juga Televengelisme, yakni ustaz-ustaz yang populer berkan media televisi seperti AA Gym, Arifin Ilham, Yusuf Mansyur, dan Jefri AlBukhori. Pada masa teknologi informasi yang menghadirkan media sosial sebagai 
media alternatif selain televisi memberikan efek kepada keagamaan yang awalnya bersifat profan kemudian menjadi sakral (Champbell, 2013). PPIM UIN Jakarta sendiri mencatat bahwa banyak 'ustaz baru' yang digemari oleh anak muda seperti UAS, UAH, Hanan Attaki, Khalid Basalah, dan Ustaz dari luar Indonesia seperti Dr. Zakir Naik (Maulana, 2018). Keberhasilan ustaz-ustaz tersebut bukan tanpa sebab, ada tim yang ikut bergerak menyebarkan video-video ceramahmereka terutama di Youtube. Sebagai tempat yang bebas, media sosial Youtube memberikan ruang bagi berbagai macam penceramah muncul di ruang tersebut, UAS sendiri videonya tersebat berkat Taffaquh Video, begitu juga UAH dengan Ahyar TV, Khalid Basalamah dengan Chanelnya juga. Massifnya video penceramah ini di Youtube bukan hanya dari chanel utamanya, namun juga beberapa chanel yang me re-post ulang postingan tersebut dengan mengedit baik backsound ataupun juga dengan judul yang provoakatif dan menarik. Bukan hanya di Youtube, video ceramah tersebutpun disebarkan juga di facebook, namun penyebaran di Instagram terlihat lebih massif lagi, karena banyaknya conten creator yang mengedit video para penceramah tersebut, dengan backsoud suara yang menyentuh serta durasi yang sangat singkat selama satu menit. Tak ayal model video ceramah seperti tersebut banyak digemari oleh anak muda generasi $\mathrm{Z}$ yang terbiasa mengkonsumsi informasi secara instant yang secara langsung juga membentuk pemahaman mereka mengenai agama.

Disinilah kemudian muncul berbagai macam conten creator di nstagram yang mengedit video ceramah ustaz-ustaz tertentu untuk disebarluaskan, salah satu akun yang paling populer di instagram adalah @fuadbakh, dalam postingannya iya aktif menanggapi segala peristiwa politik maupun agama yang suguhkan bersamaan dengan video ceramah yang terkadang juga iya kombinasikan dengan beberapa peristiwa yang ditampilkan di televisi ataupun juga yang viral di media sosial yang kemudia dia edit sebaik mungkin. Ironinya, postingannya sering kontroversi yang ditanggapi dengan berbagai macam pro dan kontra dari netizen, bahkan sering dilaporkan bahwa postingannya berbahaya yang kemudian ditindak lanjuti instagram untuk memblokirnya.

\section{Hasil dan Pembahasan \\ Profil Fuadbakh}

Nama pengguna akun @fuadbakh adalah Fuad Bakhtiar, ia bekerja sebagai editor di salah satu TV swasta nasional. Fuad Bakhtiar lahir di Tegal, pada tanggal 5 februari 1991, tinggal di Kebon Jeruk, Jakarta Barat bersama istrinya yang bernama Aria Shinta. Akun @Fuadbakh mulai populer ketika ia mendubbing dialog drama Korea "Descendents of the Sun". Suara Dr. Kang yang didubbing istrinya dan suara Kapt. Yoo Si Jin yang didubbing oleh Fuad Bakhtiar sendiri. Isi dialognya adalah seputar permasalahan kepastian mengenai sebuah hubungan 


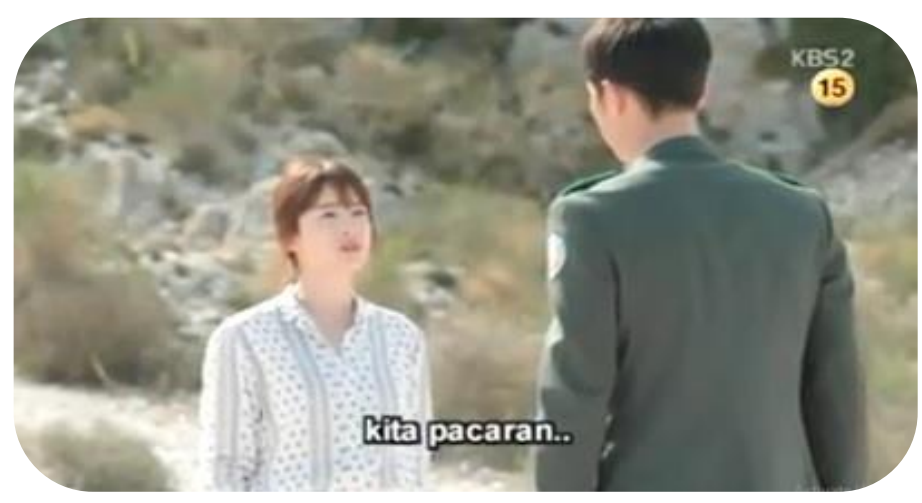

Gambar 1

Dr. Kang: Tunggu bentar, kamu tu kenapa sih?

Kapt. Yoo Si Jin: Apalagi yang harus diperdebatkan

Dr. Kang: Kita pacaran, memang ada yang salah ya

Kapt. Yoo Si Jin:Saat pacaran wajar bagi kebanyakan orang, disitulah kita harus melawan "wa mal hayatud dunyaa illa mata'ul ghuruuri (Al-Hadid: 20)" "Dan tidaklah kehidupan dunia hanyalah kesenangan yang menipu dan memperdaya." "Wazayyana lahumus syaithan a'malahum, syaitan itu senantiasa menghias amalan-amalan yang buruk seolah-olah terasa indah" dan sekarang aku baru menyadari mencintaimu harus dengan cara yang benar

Dialog di atas terinspirasi dari kisah hidup Fuad sendiri bersama istrinya yang tidak memiliki pengalaman berpacaran. Berangkat dari pengalaman itulah Fuad kemudian mengemas dakwah dengan menggunakan kemampuan konten kreator, kepopulerannya mulai tampak ditahun 2014-2015. Belakangan konten @fuadbakh mulai jarang memposting permasalahan pacaran, di akunnya Fuad tidak hanya membicarakan kesalehan, tetapi juga permasalahan politik dan simbol-simbol iluminati. Keaktifan Fuad terhadap isu politik dimulai dari Aksi Bela Islam tahun 2016 , ia rajin menampilkan video ceramah-cermah ustaz tertentu untuk ditampilkan dalam kontennya. Sedangkan simbol-simbol Iluminati, Fuad hubungkan dengan boyband Korea yang memakain simbol-simbol satan.

\section{E. Kesalehan (Antara K_Pop dan Islam)}

Fuadbakh sendiri pada awal postingan video di Instagram di tahun 2014-2015 memposting video drama korea "Descendents of the Sun" yang iya dubbing menggunakan suara sendiri dan mengganti narasi dari pembicaraan dalam dialog drama tersebut. Misalnya mengajak untuk memakai jilbab dan meninggalkan pacaran yang dibeberapa video ia selipkan ceramah semisal Felix Xiau dan Buya Yahya, hal tersebutpun sukses membuatnya digemari banyak follower terutama anak muda. 


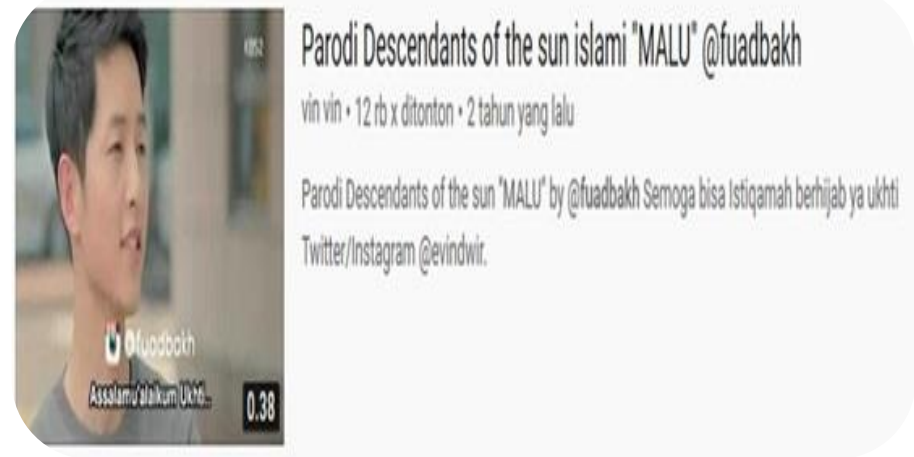

Gambar 2

Dari potongan-potongan videonya yang berdurasi satu menit di instagram kemudian di upload di youtube menjadi kumpulan video dari kanal Youtube Fuad Bakhtiar sendiri atau dari kanal Youtube yang me-repost ulang video Fuad. Perkawinan antara budaya populer dan Islam sebenarnya bukan menjadi hal yang baru, fenomena ini bisa dilacak pada tahun 1980-an yang pada awalnya marak budaya Barat yang ditampilkan melalui majalah, film, novel, ataupun juga komik. Situasi tersebut membuat khawatir kalangan islamis atau disebut dengan istilah "moral panic" atas tersemainya buday Barat, kemudian atas inisiatif Halvy Tiana Rose dan Asma Nadia membuat tandingan dengan menerbitkan majal An-Nida, sebuah majalah yang berbentuk populer namun dengan muatan islami (Kailani, 2011; Kailani, 2012).

Seiring dengan munculnya gerakan Islamis, budaya populerpun diislamisasikan dengan hadirnya sinetron-sinterong religi yang ada ditelevisi, populernya novel islami karya Habiburrahman dan Asma Nadia yang banyak diminati oleh remaja, belakanganpun film yang bernuanasa islamis mulai muncu dintandai dengan kehadiran film Ayat-ayat Cinta, Ketika Cinta Bertasbih, Assalamualaikum Beijing, 99 Cahya Langit di Eropa, dan lain-lain yang kesemuanya diangkat dari novel, yang secara umum menggabarkan bagaimana Islam di luar negeri yang dibumbui juga dengan kisah cinta.

Dalam postingannya, Fuad mengkombinasaikan antara drama Korea Decedent of The Sun dengan Islam. Ihwal ini tidak lepas dari kepopuleran budaya Korea yang berkembangan di Indonesia baik melalui film, drama, musik, dan Iklan. Budaya Korea ini banyak digemari oleh anak muda, terutama para gadis remaja yang mengidolakan artis-artis Korea. Tampilan artis Korea yang rupawan, putih dan sipit, membuatnya banyak digemari oleh Remaja. Meskipun menggemari artis-artis Korea, remaja Muslimah di Indonesia tetap berpenampilan memakai jilbab. Ihwal ini menunjukka negosisasi antaram budaya populer Korea dengan Islam (Heryanto, 2018).

Kepopuleran drama Korea inilah yang dijadikan Fuad sebagai mediasinya dalam berdakwah. Ia menjadi konten kreator video di Instagram dengan memanfaatkan dubbing dan menggantinya dengan dialog yang lebih Islami dan 
disenangi oleh anak muda. Dialognya berisi seputar pacaran, jilbab, pergaulan, dan hal-hal yang tidak jauh dari permasalahan anak muda. Meskipun belakangan Fuad menjadi resistensi terhadap budaya Korea karena ia anggap memiliki seubah konspirasi Satan $^{1}$ ataupun Iluminati².

\section{F. K-Pop; Konspirasi dari Iluminati dan Satan}

Berbeda dengan tahun awalnya yang mengakomodasi budaya populer Korea dengan lebih Islami, pada beberapa tahun terakhir Fuad lebih banyak menampilkan konten video yang menghubungkan budaya Korea dengan Konspirasi Iluminati.

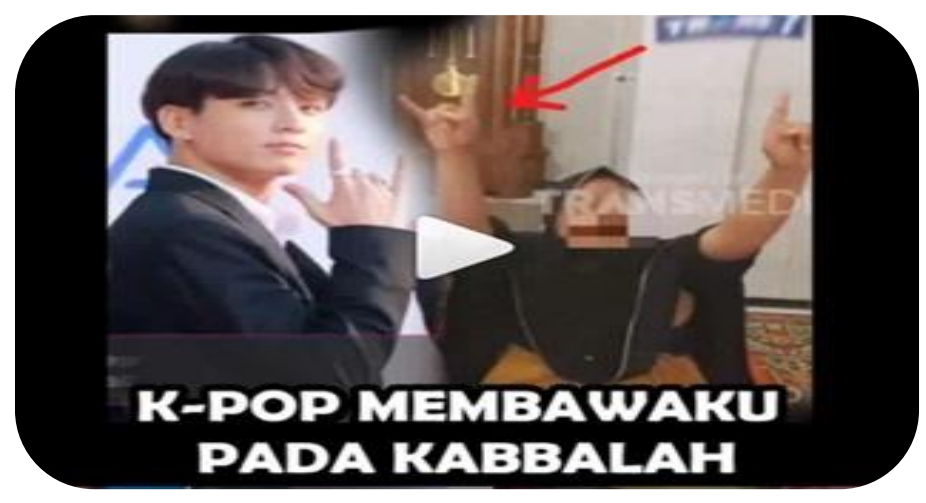

Gambar 3

Postingan di atas Fuad ambil dari tayangan di TV swasta yang menampilkan seorang wanitas kesurupan karena mendengarkan musik-musik K-Pop. Jari yang ditunjukkan wanita tersebut menampilkan simbol Kabbalah yakni simbol dari Satan. Video wanita kesurupan ini dilanjutkan dengan artis-artis K-pop yang membentuk simbol jari Kabbalah. Postingan mengenai hubungan K-pop dengan Satan atau Iluminati sering Fuad tampilkan, terutama ia tunjukkan kepada penggemara K-pop.

Efek dari unggahan Fuad terhadap bahaya K-Pop, menginspirasi gadis remaja yang mengidolakan artis K-pop untuk membakar dan menghancurkan hal-hal yang berhubungan dengan artis K-Pop yang dia idolakan seperti kaset ataupun juga poster artis K-Pop. Meskipun Fuad tidak secara langsung memberikan instruksi untuk membakar dan menghancurkan hal-hal yang berhubungan dengan K-Pop, namun ia telah menginspirasi melalui video pendek yang dibuatnya.

\footnotetext{
${ }^{1}$ Satan dalam potingan Fuad digambarkan melalui simbol-simbo yang dibawakan oleh orang-orang terkenal ataupun juga artis-artis populer. Simbol tersebut bisa beentuk kalung, simbol gerakan tangan, ataupun simbol berupa Satan seperti tanduk

2 Pembicaaran Ilumnati sering dihubungkan dengan sekolompok orang yang berkonspirasi membentuk tatanan dunia baru. Simbol Iluminati ditampilkan dengan mata satu atau segitiga, dalam postingannya Fuad biasa menghubungkan artis dan tokoh dengan simbol iluminati.
} 


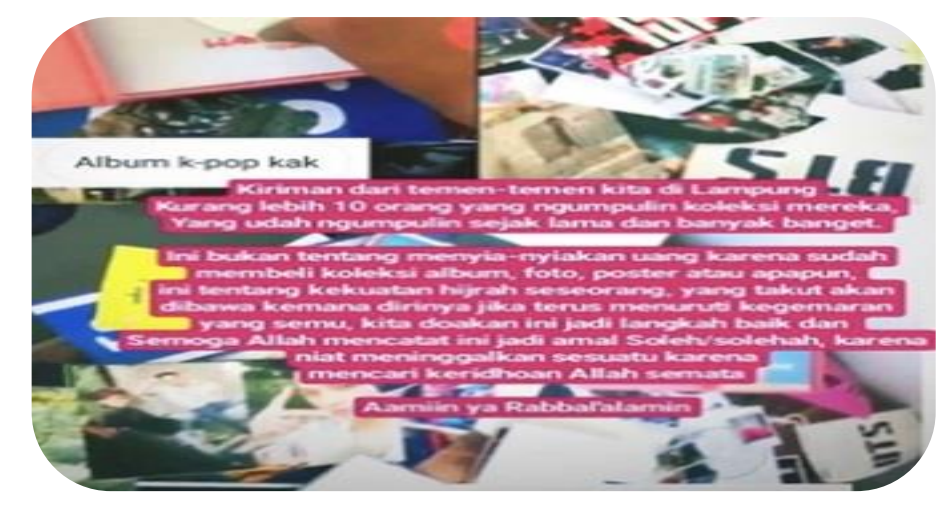

Gambar 4

Berhasilnya dakwah yang dilakukan Fuad tidak lepas dari model media sosial instagram yang menjadi tempat dakwah yang efektif (Nisa, 2018; Baulch \& Pramiyanti, 2018). Nisa menyebut model dakwah di instagram dengan 'soft da' $w a$ ', yakni dakwah yang ditampilkan melalui gambar dan meme yang bisa memberikan pemahaman secara singkat namun 'mengena'. Keberhasilan dakwah Fuad juga ditunjang oleh tampilannya yang ikonik, yakni menggunakan judul yang dapat menarik pengguna media sosial, hal ini dikarenakan insftruktur media sosial yang lemah. Sehingga pesan-pesan yang ditangkap di media sosial adalah pesan-pesan yang memiliki kata-kata yang ikonik. Perihal ini dicontohkan oleh Merlyna Lim seperti "CicakVSBuaya” atau “\#Koinuntukprita” (Lim, 2013). K-pop adalah salah satu di antara hal-hal yang viral di media sosial, terutama ramai diperbincangkan oleh remaja Muslimah yang menggemari K-pop. Hal tersebutlah yang kemudian direspon oleh Fuad dalam mengkritik penggemar K-pop dengan menghubungkan dengan fenomena konspirasi seperti Satan dan Iluminati.

\section{G. Komodifikasi Agama}

Semenjak runtuhnya Orde Baru, Islamisasi ruang publik mulai terjadi. Hal ini tidak lepas dari peran media televisi yang menampilkan ustaz-ustaz selebriti dan produk-produk Islami seperti pakaian dan obat-obatan. Konsumsi keagamaanpun terkomudikasi, yaitu agama tidak lagi menjadi sebuah doktrin dan hal yang sakral namun menjadi sebuah produk kesalehan (Hasan, 2009). Produk kesalehan ini menjelma dalam bentuk pesan dakwah SMS oleh ustaz-ustaz selebriti, yang beriringan dengan meningkatnya permintaan layanan-layanan yang memenuhi tuntutan pasar akan bimbingan Islam yang cepat, mudah diakses, dan sesuai gaya hidup. Pesan dakwah itu dikemas dengan tema yang dihadapi oleh masyarakat Muslim, baik mengenai rumah tangga, keuangan, pekerjaan dan lain-lain(Fealy, 2008) .

Proses komodifikasi banyak merambah keberbagai bentuk mulai dari meningkatnya tren pakaian muslim, lagu-lagu religi, novel religi, sinetron religi, dan film religi. Komodifikasi agama ini semakin berlanjut ketika hadirnya media sosial pada tahun 2010-an yang memberikan ruang bagi siapapun menyebarkan pesanpesan agama. Media sosial semakin meningkatkan Islamisasi ruang publik yang 
ditandai dengan wacana 'hijrah' dan isu keagamaan yang terus-terusan jadi perbincagan di ruang media sosial. Ihwal tersebutpun menjadikan komudifikasi agama semakin meningkat dan banyak dimanfaatkan oleh akun-akun keagamaan

Sala satu akun keagamaan yang memanfaatkan komodikasi agama adalah Fuad, Kepopulerannya sebagai konten kreator video dakwah, ia manfaatkan untuk meraih keuntungan melalui iklan yang ditampil baik di akun ataupun di instastory. Perihal ini juga disoroti Eva F. Nisa dalam akun @duniahijab dan @ukhtisally yang memanfaatkan akun-akun keagamaan dalam menjual produk-produk Islama sembari menyampaikan pesan dakwah.

\section{H. Kontroversi Fuad di Instagram}

Sejauh pengamatan kami melihat aktivitas Fuad di instagram, meskipun ia memiliki pengikut yang banyak dan memiliki video dakwah singkat yang menarik. Konten yang dibuat oleh Fuad seringkali diblokir oleh pihak instagram dikarenakan tidak sesuai dengan peraturan yang diolah oleh pihak instagram ataupun juga dilaporkan oleh pihak-pihak tertentu.

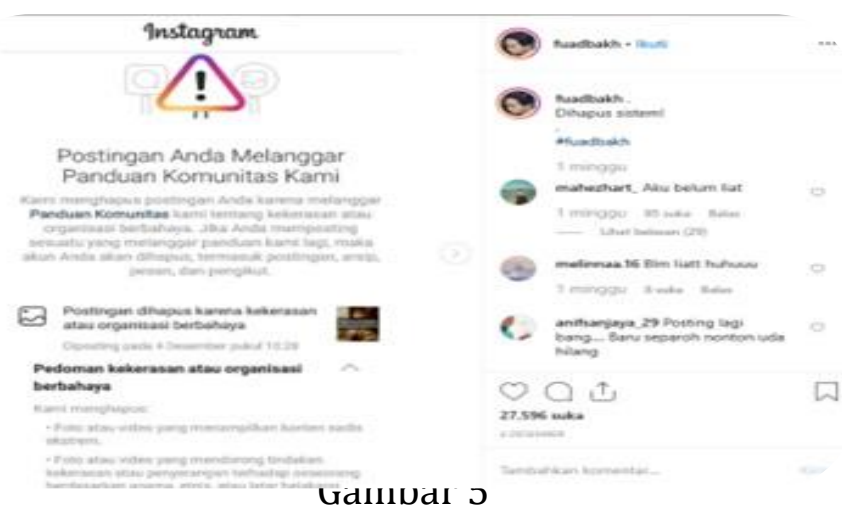

Postingan Anda Melangar Panduan Komunitas Kami. Kami mengahpust postingan Anda karena melanggar pandukan komunitas kami tentang kekerasan atau oganisasi berbahaya. Jika anda mempostinga sesuatu yang melanggar panduan kami lagi, maka akun Anda akan dihapus, termasuk postingan, arsip, pesan, dan pengikut.

Video Fuad yang dihapus oleh pihak instagram dikarenkan berisi konten kekerasan dan organisasi berbahaya. Video yang biasa ditampilkan Fuad adalah isu agama yang sering diperbincangkan oleh warganet. Ia kemudian mencari pendapat seorang ustaz yang kemudian diedit menjadi video singkat. Beberapa videonya kemudian banyak dilaporkan karena mengandung ujaran atau simbol kebencian. 


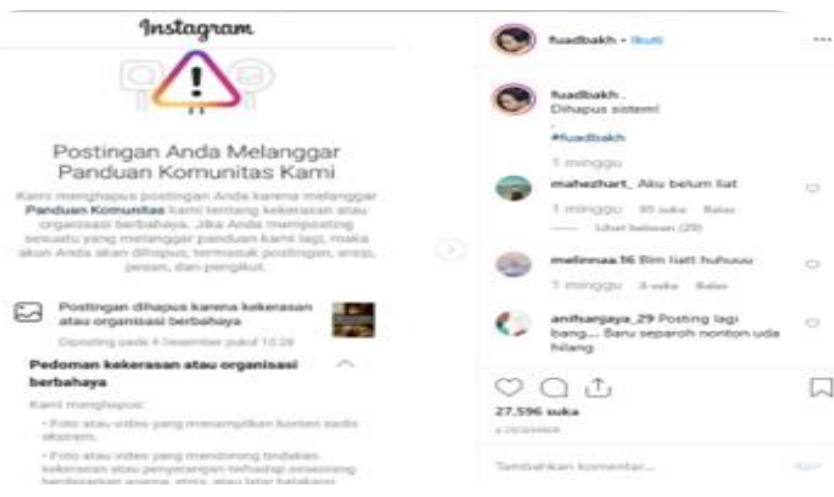

Gambar 6

Video Fuad yang dihapus oleh pihak instagram, kemudian mendaptkan respon dari warganet. Fuad mengupload video yang telah dihapus oleh pihak instagram dengan caption seperti "Dihapus sistem, kenapa hayo", Perihal tersebutpun mendapat komentar dari warganet seperti akun:

@nrahmayani_Karna dalam video tersebut si bapak abu menyebarkan kebencian(?) @toni_budianto (emot tertawa) ayo kenapa dihapus videonya ayo... walaupun dihapus juga, tetap aja udah kecatan dengan \& baik oleh malaikat. Setiap katakatanya mas-mas yang pakai kacamata itu (emot tertawa) + orang yang hapus ini video

Fuad melontarkan kesalahan kepada sistem atas akun yang dihapus. Tidak lepas dari muatan poltik dalam video pendeknya, yang condong banyak mengkritik pemerintahan Jokowi. Ditambah pada pemilu 2019, Fuad secara terang-terangan mendukung pasangan Prabowo-Sandi yang juga diusung oleh Alumni 212. Sintemen keagamaan yang banyak bergesekan di ruang media sosial dimanfaatkan Fuad untuk mengambil berbagai macam ustaz untuk mendukung setiap argumennya. Baik yang ada di kanal youtube ataupun di acara-acara politik televisi seperti ILC (Indonesia Lawyer Club).

\section{Simpulan}

Saya beragumen bahwa Fuad di media sosial instagram adalah keberlanjutan situs-situs Islam keras yang melontarkan narasi kebencian. Situs-situs radikal menurutu PPIM UIN Jakartan seperti eramuslim.com, VOA-Islam, arrahman.com, dan thoriquna. Com. Hanya saja Fuad menampilkan narasi kebencian tersebut melalui instagram dengan menayangkan video-video ceramah dan narasi yang sesuai dengan ia inginkan. Kemasan Islam keras ini ia olah dengan mengkombinasikan dengan budaya populer atau biasa disebut dengan Islamisme Populer (Hasan, 2018). Selain itu, ruang media sosial tidak hanya menjadikan tempat yang profan namun juga sakral, di mana pengikut dari Fuad merasa diri mereka berada dipihak yang paling Islami berdasarkan video-video pendek yang disodorkan oleh Fuad. 
Ada dua hal yang sering Fuad tampilan daam postingan instagram. Pertama, mengenai budaya populer Korea yang ia dubbing semisal drama Korea Decedent of The Sun dan mengenai budaya K-Pop yang memiliki hubungan dengan Satan atau Iluminati. Kedua, Postingan Fuad mengenai permasalahan politik, terutama politik anti-Jokowi. Ia menampilkan ustaz-ustaz yang tidak sepakat dengan pemerintahan Jokowi. Hal inipun semakin terlihat saat Fuad secara jelas mendukung Prabowo sebagai calon presiden 2019. Beberapa video-video ustaz yang mendukung Prabowo dan anti Jokowi banyak Fuad hadirkan dalam postingannya.

\section{Daftar Rujukan}

Baulch, E., \& Pramiyanti, A. (2018). Hijabers on Instagram: Using Visual Social Media to Construct the Ideal Muslim Woman. Social Media + Society, 1-15.

Champbell, H. A. (2013). Understanding Religious Practice In New Media Worlds. London and New York: Routledge.

Eickelman, D. F., \& Anderson, J. W. (2003). New media in the Muslim World: The Emerging Public Sphere. Bloomington: IN: Indiana University Press

Fealy, G. (2008). Consuming Islam: Commodified Religion And Aspirational Pietism In Contemporary Indonesia (G. Fealy \& S. White, ed.). Singapore: Institute Of Southeast Asian Studies Singapore.

Fealy, G., \& White, S. (Ed.). (2008). Expressing Islam: Religious Life and Politics in Indonesia. Singapore: Institute Of Southeast Asian Studies Singapore.

Hasan, N. (2009). The Making of Public Islam: Piety, Agency, and Commodification on The Landscape of The Indonesian Public Sphere. Contemporary Islam, 3 (3), 229-250.

Heryanto, A. (2018). Identitas dan Kenikmatan (E. Sasono, penerj.). Jakarta: KPG (Kepustakaan Populer Gramedia).

Jannah, I. L. (2018). Kontestasi Makna Hijab Dalam Ruang Media Sosial Instagram (Sunarwoto, ed.). Yogyakarta: Arti Bumi Intaran.

Kailani, N. (2011). Kepanikan Moral dan Dakwah Islam Populer (Membaca Fenomena "Rohis" di Indonesia). Analisis, XI, 1-6.

Kailani, N. (2012). Forum Lingkar Pena and Muslim youth in contemporary Indonesia. RIMA: Review of Indonesian and Malaysian Affairs, 46 (1).

Maulana, D. (2018). Situs-Situs Islam: Kontestasi Narasi Radikal dan Moderat.

Pusat Pengkajian dan Masyarakat (PPIM) UIN Syarif Hidayatullah Jakarta, 1 (3).

Nisa, E. F. (2018). Creative and Lucrative Da'wa: The Visual Culture of Instagram amongst Female Muslim Youth in Indonesia. Asiascape: Digital Asia, 5, 6899.

Saifullah, M. (2018). Beyond Muslims Panic: An Exploration Upon Instagram Matchmaker In Indonesia. Jurnal Multikultural dan Multireligius, Vol. 17, No. 2, 359-373. 
Romario

Turner, B. S. (2007). Religious Authrity and the New Media. Theory, Culture \& Society, 24 no. $2,117-134$. 